\title{
Quantitative characterization of unsaturated and trans fatty acids in ewe's milk fat
}

\author{
Hanane GOUDJIL ${ }^{\mathrm{a}}$, Javier FONTECHA ${ }^{\mathrm{a}}$, Pilar LUNA ${ }^{\mathrm{a}}$, \\ Miguel Angel de la FUENTÉa ${ }^{\mathrm{a} *}$, Leocadio ALONSO ${ }^{\mathrm{b}}$, Manuela JUÁREZ ${ }^{\mathrm{a}}$ \\ a Instituto del Frío (CSIC), José Antonio Novais 10, Ciudad Universitaria s/n, 28040-Madrid, Spain \\ b Instituto de Productos Lácteos de Asturias (CSIC), 33300-Villaviciosa, Asturias, Spain
}

Received 4 February 2004 - Accepted 15 April 2004

Published online 4 August 2004

\begin{abstract}
Ewe's milk fat obtained from the milk of five different herds were studied to characterize main and minor fatty acids using a combination of gas chromatography and mass spectrometry. In order to assess monounsatured trans fatty acids content, fatty acid methyl esters (FAME) were fractionated by silver ion thin-layer chromatography prior to gas chromatography analysis. Trans fatty acids (TFA), including conjugated linoleic acid, represented $4.9 \%$ of the total FAME; most of them belonged to C18:1 trans isomers (2.9\%) with a small range of variation (2.5-3.2\%). The distribution profile of trans-C18:1 molecules indicated that more than half were trans-11, whereas the proportion of potentially unhealthy compounds (trans-10 and trans-9 C18:1) was less than $10 \%$. Mean trans-C16:1 content was $0.25 \%$ of total FAME. The sum of the different trans-C18:2 isomers (excluding conjugated linoleic acid) was $0.88 \%$ and $\mathrm{C} 18: 3$ trans isomers represented $0.16 \%$.
\end{abstract}

Ewe's milk / fatty acid / trans fatty acid

Résumé - Caractérisation quantitative des acides gras insaturés et trans de la matière grasse du lait de brebis. Les acides gras mineurs et majeurs du lait de brebis provenant de cinq troupeaux différents ont été caractérisés par chromatographie gazeuse associée à la spectrométrie de masse. En vue de connaître le contenu en acides gras monoinsaturés trans, les esters méthyliques des acides gras ont été fractionnés en recourant à la chromatographie sur couche mince à l'ion argent suivie d'une analyse par chromatographie gazeuse. Les acides gras trans, incluant l'acide linoléique conjugué, représentaient 4,9\% du total des esters méthyliques des acides gras. La plupart d'entre eux appartenaient aux isomères trans du C18:1 (2,9\%) avec une variation faible entre les échantillons (2,5-3,2\%). Le profil de distribution des molécules C18:1 trans montraient que plus de la moitié étaient des trans-11, tandis que les proportions de trans-10 et trans-9, potentiellement nuisibles à la santé, étaient inférieures à $10 \%$. La teneur moyenne en C16:1 trans était de l'ordre de 0,25\% du total des esters méthyliques des acides gras. Le total des différents isomères C18:2 trans (à l'exception de l'acide linoléique conjugué) et C18:3 représentait respectivement $0,88 \%$ et $0,16 \%$ du total.

Lait de brebis / matière grasse / acide gras trans

\footnotetext{
* Corresponding author: ifraf91@if.csic.es
} 


\section{INTRODUCTION}

Although the world production of ewe's milk (8 million tonnes, representing $1.3 \%$ of the total world milk production) is relatively low compared with the cow's milk market, ewe's milk products are widely consumed in the Mediterranean and Middle East where climatic and geographic conditions are not the most ideal for cattle rearing. Ewe's milk is primarily for cheese production and, in some countries, it is used in the manufacture of yogurts or serum cheeses. The fat/protein ratio is higher in ewe's than cow's milk and therefore cheese yield from ewe's milk is also higher (approximately $15 \%$, compared with $10 \%$ for cow's milk). Moreover, ewe's milk lipids are quantitatively more important than in the other ruminant species. This high content in lipids means that ewe's milk is a suitable substrate for the manufacture of cheese due to the characteristic flavor that it lends to these products.

In the lipid fraction of ewe's milk, the most abundant fatty acids are palmitic, oleic, miristic and estearic [12, 15, 19, 24, 26]. Short- and medium-chain fatty acid content (caproic, caprilic and capric) is higher in ewe's than cow's milk. Of the C4-C8 fatty acids present, greater than $95 \%$ were specifically attached to the glycerol molecule in the position 3 [12]. These acids are important since they are associated with the organoleptic characteristics of ovine cheese and they can also be used as a criterion for detecting the fraudulent addition of milk from other ruminant species $[9,25]$. As regards the minor fatty acids, although some studies mention differences in the C11, C12:1, C14, C14:1 and C15 content between cow's and ewe's milk [25], there is currently not very much data available on these acids in the literature. Information about unsaturated fatty acids, mainly trans isomers, is not abundant either [15, 24, 26]. The nutritional importance of trans fatty acids (TFA) has been widely stressed on in recent years $[6,17,18,27]$. Physiological functions of TFA, specially its possible role in atherosclerosis, the level of blood cho- lesterol, and coronary heart disease is of concern, but still subject to controversy. Conjugated linoleic acid (CLA) and possibly also trans vaccenic acid (trans-11 C18:1) (TVA), seem to have beneficial effects on different body functions as well as a protective action on some pathologies such as cancer, obesity, cardiovascular disease and diabetes. Although some works have provided data on monounsaturated trans fatty acid (MUTFA) isomers in ewe's milk [4, 24, 30] there is hardly any information on polyunsaturated trans fatty acid (PUTFA) isomers.

The purpose of this research was to determine the range of variation in the composition of major and minor fatty acids in ewe's milk. We will focus in particular on MUTFA and PUTFA isomers. To achieve this aim, milk fats from five different ovine herds were investigated by capillary column gas chromatography (GC). Analyses of MUTFA were based on the combination of silver ion thin-layer chromatography $\left(\mathrm{Ag}^{+}\right.$-TLC) with GC and mass spectrometry (MS) to obtain the contents of MUTFA positional isomers.

\section{MATERIALS AND METHODS}

\subsection{Samples}

Milk samples were collected at monthly intervals during the milking period from five ovine herds. They were taken from the storage tanks containing milk from the whole herd. Each herd consisted of a different breed: $\mathrm{CH}$ (Churra breed with 130 head), W (Awasi breed with 130 head), AxC (cross between Assaf and Castellana breeds with 170 head), M (Manchega breed with 2200 head) and A (Assaf breed with 480 head). The herds were located in different places in Spain to ensure a wide variety of milk composition. A total of 45 samples was collected over the year. Fats were extracted following a procedure described by ISO [7], exposed to a stream of $\mathrm{N}_{2}$ and frozen at $-20{ }^{\circ} \mathrm{C}$ in amber vials until analysis. The mean fat content of the different herds 
ranged from $7.5-9.8 \%$. All the ovine milk fat samples extracted from each herd were combined in equal volumes to obtain five mixture samples.

\subsection{Standards}

An anhydrous milk fat with a certified fatty acid composition (reference material BCR-164, obtained from the Commission of the European Communities, Brussels, Belgium) was used to determine the fatty acid methyl esters' (FAME) response factors. Tentative identification of trans-C18:2 and trans-C18:3 isomers was done by comparing the equivalent chain-length values of FAME obtained with those of reference oils: partially isomerized linseed oil FAME, refined rapeseed oil (BCR 686), partially hydrogenated sunflower seed oil (BCR-688) and a blend of palm oil and partially hydrogenated sunflower seed oil (BCR-687), which had served as test material in the research project SMT4-CT97-2144 of the European Union.

Besides this test material, FAME pure isomers (C18:1: cis-9; cis-13; trans-9; trans-11; trans-13) and polyunsaturated (PUFA) mixtures (C18:2 mixture: trans-9 trans $-12+$ cis -9 trans $-12+$ trans -9 cis $-12+$ cis-9 cis-12; C18:3 mixture: trans -9 trans12 trans $-15+$ trans -9 trans -12 cis $-15+$ trans -9 cis- 12 trans $15+$ cis -9 trans -12 trans $-15+$ cis- 9 cis-12 trans $-15+$ cis- 9 trans-12 cis-15 + trans -9 cis-12 cis-15 + cis-9 cis-12 cis-15) supplied by Supelco (Bellefonte, USA) were also used as standard.

\subsection{Preparation of fatty acid derivatives}

FAME were prepared by base-catalyzed methanolysis of the milk fat $(2 \mathrm{~N} \mathrm{KOH}$ in methanol) according to ISO [8]. In order to confirm the correctness of trans-C18:1 peak assignment positional isomers, FAME were converted to 4,4 dimethyloxazoline (DMOX) derivatives according to Fay and Richli [5] and analyzed by GC-MS.

\subsection{Silver ion thin-layer chromato- graphy $\left(\mathrm{Ag}^{+}\right.$-TLC)}

FAME were fractionated according to the number and geometry of double bonds by $\mathrm{Ag}^{+}-\mathrm{TLC}$ following the Precht and Molkentin procedure [20] modified by Alonso et al. [1]. After the chromatographic run, the bands corresponding to the saturated and trans monoenoic FAME were scraped, dissolved in heptane and used for $\mathrm{GC}$ analysis. To calculate the total content of trans-C18:1 isomers, the ratio $\mathrm{C} 18: 0$ to total trans-C18:1 was determined in the saturated plus trans monoenoic $\mathrm{Ag}^{+}$-TLC fraction and was related to the $\mathrm{C} 18: 0$ content of total FAME.

\subsection{Gas chromatography analysis}

Analysis of FAME was carried out on an Autosystem GC model (Perkin-Elmer, Co., Beaconsfield, United Kingdom) equipped with a FID on a CP Sil 88 column $(100 \mathrm{~m}$ $\mathrm{X} 0.25 \mathrm{~mm}$ i.d.) (Chrompack, Middelburg, The Netherlands). The column was held at $100{ }^{\circ} \mathrm{C}$ for $6 \mathrm{~min}$ after injection, temperature-programed at $5^{\circ} \mathrm{C} \cdot \mathrm{min}^{-1}$ to $210^{\circ} \mathrm{C}$, and finally held there for $30 \mathrm{~min}$. Helium was the carrier gas with a column inlet pressure set at $31 \mathrm{psi}$. The detector temperature was $250{ }^{\circ} \mathrm{C}$. For identification purposes these analyses were also performed on a gas chromatograph (Agilent, Palo Alto, USA) model HP 6890 coupled with a 5973 mass spectrometer detector (Agilent) using the same column described above. FAME were identified by standards and by comparing their mass-spectral data to the mass-spectral database in the library Wiley 7.0 (HP Mass Spectral Libraries, Palo Alto, USA).

\section{RESULTS AND DISCUSSION}

\subsection{Fatty acids global profile}

The mean values, standard deviation, and minimum and maximum percentages of major and minor fatty acids $(>0.01 \%$ of total FAME) are shown in Table I. Mean content in short-chain fatty acids 
Table I. Mean values, standard deviation and minimum and maximum contents of ewe's milk fatty acids ( $\%$ in total FAME).

\begin{tabular}{|c|c|c|c|c|}
\hline Fatty acid & Mean & $\begin{array}{c}\text { Standard } \\
\text { Deviation }\end{array}$ & Minimum & Maximum \\
\hline $\mathrm{C} 4$ & 3.51 & 0.31 & 3.07 & 3.93 \\
\hline $\mathrm{C} 5$ & 0.02 & 0.01 & 0.02 & 0.03 \\
\hline C6 & 2.90 & 0.31 & 2.68 & 3.44 \\
\hline $\mathrm{C} 7$ & 0.04 & 0.02 & 0.01 & 0.05 \\
\hline $\mathrm{C} 8$ & 2.64 & 0.42 & 2.10 & 3.27 \\
\hline $\mathrm{C} 9$ & 0.07 & 0.02 & 0.03 & 0.08 \\
\hline $\mathrm{C} 10$ & 7.82 & 1.49 & 5.54 & 9.73 \\
\hline C10:1 & 0.26 & 0.03 & 0.23 & 0.31 \\
\hline $\mathrm{C} 11$ & 0.09 & 0.03 & 0.04 & 0.14 \\
\hline $\mathrm{C} 12$ & 4.38 & 0.54 & 3.48 & 4.92 \\
\hline $\mathrm{C} 12: 1$ & 0.04 & 0.01 & 0.03 & 0.05 \\
\hline $\mathrm{C} 13$ & 0.17 & 0.03 & 0.13 & 0.22 \\
\hline iso-C14 & 0.11 & 0.02 & 0.08 & 0.14 \\
\hline $\mathrm{C} 14$ & 10.43 & 0.34 & 9.85 & 10.66 \\
\hline iso-C15 & 0.34 & 0.08 & 0.26 & 0.43 \\
\hline anteiso-C15 & 0.47 & 0.11 & 0.33 & 0.60 \\
\hline C14:1 & 0.28 & 0.13 & 0.19 & 0.50 \\
\hline $\mathrm{C} 15$ & 0.99 & 0.08 & 0.89 & 1.11 \\
\hline iso-C16 & 0.21 & 0.04 & 0.17 & 0.26 \\
\hline $\mathrm{C} 16$ & 25.93 & 2.18 & 22.47 & 28.17 \\
\hline iso-C17 & 0.53 & 0.07 & 0.44 & 0.59 \\
\hline anteiso-C17 & 0.30 & 0.04 & 0.26 & 0.36 \\
\hline C16:1 & 1.03 & 0.20 & 0.74 & 1.27 \\
\hline $\mathrm{C} 17$ & 0.63 & 0.06 & 0.58 & 0.70 \\
\hline $\mathrm{C} 17: 1$ & 0.20 & 0.02 & 0.17 & 0.22 \\
\hline $\mathrm{C} 18$ & 9.57 & 0.92 & 8.51 & 11.04 \\
\hline C18:1 (total) & 21.10 & 1.98 & 17.77 & 23.02 \\
\hline C18:2 (total) & 3.21 & 0.12 & 2.89 & 3.57 \\
\hline $\mathrm{C} 20$ & 0.45 & 0.07 & 0.36 & 0.52 \\
\hline C18:3 (total) & 0.80 & 0.21 & 0.52 & 1.04 \\
\hline C20:1 & 0.06 & 0.01 & 0.05 & 0.08 \\
\hline C18:2 conjugated (total) & 0.74 & 0.21 & 0.56 & 0.97 \\
\hline $\mathrm{C} 22$ & 0.20 & 0.05 & 0.14 & 0.26 \\
\hline $\mathrm{C} 23$ & 0.16 & 0.04 & 0.11 & 0.22 \\
\hline $\mathrm{C} 20: 4$ & 0.06 & 0.02 & 0.03 & 0.08 \\
\hline $\mathrm{C} 24$ & 0.03 & 0.02 & 0.00 & 0.06 \\
\hline No identified (total) & 0.15 & 0.05 & 0.10 & 0.22 \\
\hline
\end{tabular}


(C4-C7) was $6.5 \%$, medium-chain (C8C15) $28.1 \%$ and long-chain (C16-C24) $65.4 \%$. Most of the saturated and monounsaturated fatty acids identified in the present research, mainly the major ones, have already been detected in cow's [10], goat's [1, 13] and ewe's milk [19, 24, 25, 30]. Nevertheless, the presence of some minor long-chain fatty acids (C20:1, C22, $\mathrm{C} 23$ and $\mathrm{C} 24$ ) has not been documented in ewe's milk.

The five most significant fatty acids in quantitative terms (C16, C18:1, C14, C18 and $\mathrm{C} 10$, respectively) accounted for around $75 \%$ of total FAME (Tab. I). Individually, the percentages of major fatty acids were within the range of variation of those reported by other authors $[24,30]$. The concentration of branched-chain fatty acids was $1.96 \%$ and this percentage was made up of six different acids: iso-C14, iso- and anteiso-C15, iso- and anteiso-C17, and isoC16. Unidentified peaks represented an average $0.15 \%$ of total FAME (Tab. I). Four of them were observed in the five herds studied: one eluting between $\mathrm{C} 12$ and C12:1 (0.03\%), probably a C13 isomer; another between $\mathrm{C} 15$ and iso-C16, $(0.06 \%)$ probably a $\mathrm{C} 15$ unsaturated fatty acid; another peak between $\mathrm{C} 17$ and $\mathrm{C} 17: 1(0.03 \%)$, likely a $\mathrm{C} 18$ isomer and finally, the fourth between C22 and C23 (0.03\%), for which MS did not provide any information.

In this work the mean value of the $\mathrm{C} 12 / \mathrm{C} 10$ ratio (0.56), commonly used to test milk fat authenticity, was very similar to that reported by Iverson and Sheppard [9] and Wolff [30] (0.58) in ovine milk and cheese samples, respectively, and it was also the same as that (0.57) more recently observed by Precht et al. [24]. These authors reported a very different value in cow's milk fat for this ratio (1.1-1.2). Another of the ratios used for assessing the authenticity of the milk is $\mathrm{C} 15 / \mathrm{C} 14: 1$; in the present work this ratio was 3.54. When the C15/C14:1 ratio for cow's milk is compared, the differences are considerable, because values reported for this ratio are much lower (0.8-1.6; Ramos and Juárez [25]). However, differences in the C15/C14:1 ratio cannot be established for ewe's and goat's milk fat because the data on this ratio for goat's milk fat are very different ((3.8) Alonso et al. [1]; (6.6) Wolff [30]).

\subsection{MUTFA content and profile}

MUTFA content represented an average $3.15 \%$ of the total FAME. Most of them belonged to trans-C18:1 isomers (2.9\%) with a small range of variation between the different samples (2.5-3.2\%) (Tab. II). Almost $14 \%$ of C18:1 geometric isomers were trans. The total percentage of trans-C18:1 isomers measured in this study was much higher than the percentage found in goat's milk $[1,13]$. In general terms, ewe's milk has been highlighted as having the highest levels of trans C18:1 in all the ruminants $[24,30]$.

Table II shows the relative distribution of trans-positional C18:1 isomers in ewe's milk fat fractionated by $\mathrm{Ag}^{+}-\mathrm{TLC}$ prior to GC analysis. The pattern is qualitatively identical to that presented by trans-C18:1 isomers in cow's [10] and goat's milk [1, 13, 24]. TVA is the main constituent acid and varies between 45 and $57 \%$. The second main trans-C18:1 isomer is the unresolved trans-13/trans-14 pair (20\%). It has been discovered that it is only under low-temperature conditions and using long isothermal GC programs [24] that these isomers can be separated and that their concentrations are similar in cow's milk fat. Elaidic acid (trans-9 C18:1) is only present in considerably low amounts, as it represents on average only $2.6 \%$ (2.3-2.8\%), whereas minor isomers (trans-5 and trans-4 C18:1) were not quantified.

Despite the fact that the trans-6 to trans8 group $(2.98 \%)$ remains unresolved, we would suggest that trans- $8 \mathrm{C} 18: 1$ could be the major isomer in that peak. C18:1 DMOX derivatives possess mass spectra, easily recognizable for determining the double bond position. Figure 1 shows the DMOX derivative mass spectrum of the trans- 6 to 


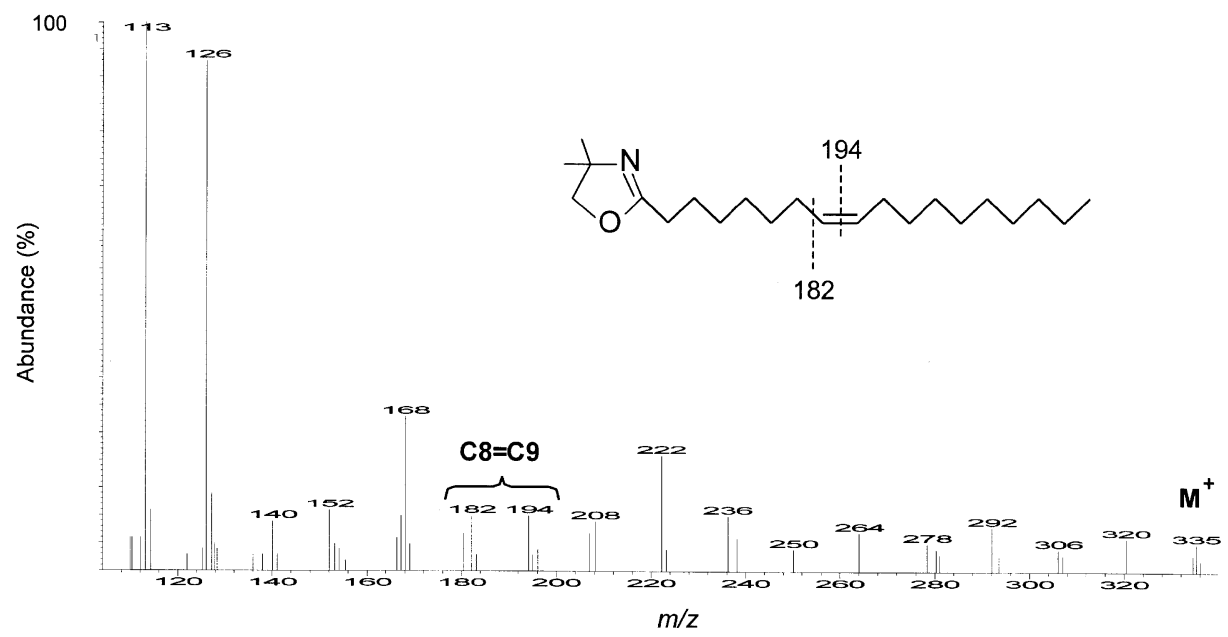

Figure 1. Electron impact mass spectrum of 6- to 8-trans C18:1 DMOX derivative peak showing a double bond between atomic mass unit $m / z, 182$ and $194 . \mathrm{M}^{+}$corresponds to molecular ion.

Table II. Total content of trans-C18:1 and trans-C16:1 (wt \% of total methyl esters) in ewe's milk fat and proportions of the different trans-C18:1 isomers (wt \% of total trans-C18:1) isolated by silver thin-layer chromatography and analyzed by gas chromatography.

\begin{tabular}{lcrrrr}
\hline Item & $\begin{array}{c}\text { trans-C18:1 } \\
\text { Isomer }\end{array}$ & Mean & $\begin{array}{c}\text { Standard } \\
\text { deviation }\end{array}$ & Minimum & Maximum \\
\hline Total trans-C16:1 & & 0.25 & 0.05 & 0.17 & 0.31 \\
Total trans-C18:1 & & 2.90 & 0.28 & 2.45 & 3.21 \\
& Trans-6 to trans-8 & 2.92 & 0.29 & 2.44 & 3.20 \\
& trans-9 & 2.61 & 0.20 & 2.32 & 2.79 \\
& trans-10 & 6.28 & 0.63 & 5.49 & 6.95 \\
& trans-11 & 51.23 & 5.19 & 44.76 & 56.71 \\
& trans-12 & 7.11 & 0.44 & 6.38 & 7.56 \\
& Trans-13 + trans-14 & 20.01 & 0.83 & 19.29 & 21.43 \\
& trans-15 & 3.63 & 0.28 & 3.32 & 3.97 \\
& trans-16 & 6.21 & 0.50 & 5.56 & 6.74 \\
\hline
\end{tabular}

trans-8 C18:1 peak. This spectrum forms the pattern predicted from the work of Zhang et al. [31] for trans-8 C18:1 and is nearly identical to that reported for this isomer by Mossoba et al. [14], with two prominent ions $(\mathrm{m} / \mathrm{z}, 168$ and 222) and a gap of 12 atomic mass units between $\mathrm{m} / \mathrm{z}=182$ 194 to locate the double bond. Spectra from trans-6 and trans-7 C18:1 DMOX exhibit different ion profiles $[3,14]$. The pattern observed in Figure 1 was similar for the same peak in the five ovine herds studied. Other evidence in this direction comes from previous observations on cow's milk fat: Parodi [16] found five times as much trans-8 C18:1 as trans- 6 or trans-7 C18:1 acids in butter fat using ozonolysis. Furthermore, Aro et al. [2] did not detect these isomers in butter but reported a small percentage of trans-8 C18:1. 
The implications of trans-C18:1 isomer distribution could be important from a nutritional point of view. Wolff [30] noted that ewe's milk fat could be important as a source of dietary trans-C18:1 acid in countries where cattle rearing is not really feasible, particularly the Mediterranean region. It has been recommended that for people who wish to limit their trans intake, goat's cheese should thus be preferred to bovine or ovine dairy products. However, although a high intake of MUTFA has been associated with the risk of coronary heart disease and myocardial infarction, other aspects should also be highlighted. It has been suggested that TFA isomers from dairy products and those from partially hydrogenated vegetable oils may have different effects on the risk of coronary heart disease. Trans-9 C18:1 isomer, the component most widely studied in relation to the intake of TFA and the risk of coronary disease, represents a very small fraction $(2.6 \%)$ of the total trans-C18:1 with not very much variability between the herds (Tab. II). In contrast with the majority of hydrogenated vegetable oils enriched in trans-10 and trans-9 C18:1 acids, consumption of food derived from ovine milk would represent a very low intake.

On the other hand, trans-11 C18:1 was the most abundant trans isomer in ewe's milk fat, comprising $51 \%$ (variability between 45 and $57 \%$ ) of total trans-C18:1 isomers (Tab. II). The importance of TVA lies in its role as a precursor of rumenic acid (RA) (cis-9 trans-11 C18:2) synthesis in the mammary gland and other tissues. The literature increasingly describes the anti-carcinogenic and anti-atherosclerotic effects of RA, the biologically active form of CLA. Recent studies [10] have found that most of the RA in ruminant milk fat is synthesized endogenously from 11-trans C18:1 by desaturases. Furthermore, TVA has also been found as an RA precursor in human tissues [28]. If this evidence were confirmed, remarkable benefits could be obtained from ewe's milk fat product consumption.
As for the trans-C18:1 isomers, accurate and reliable trans-C16:1 determination can only be obtained by using $\mathrm{Ag}^{+}$-TLC/GC combination [1]. $\mathrm{Ag}^{+}-\mathrm{TLC}$ allows the removal of interfering branched C17:0 acids and cisC16:1. The trans-C16:1 total content found in this work was $0.25 \%$ (Tab. II), similar to levels previously reported in ewe's cheese and milk and slightly higher than in cow's and goat's milk [1, 4, 30]. Quantitatively, the trans-C16:1 only represent $8 \%$ of the sum of the trans-C16:1 plus trans-C18:1 isomers, therefore they do not seem to be of great nutritional importance.

\subsection{Octadecadienoic isomers}

Mean linoleic acid content (cis-9 cis-12 C18:2) accounts for $73 \%$ of the total C18:2, whereas the trans-C18:2 isomer group, excluding CLA, represents slightly more than a quarter of this fraction and $0.88 \%$ of the total FAME. The data for trans-C18:2 reported for cow's milk are similar or slightly higher, although the ranges of variation are large $(0.6-1.44 \%)$ because they vary according to diet [21-23].

Leaving aside linoleic acid, four peaks including five isomers were separated and quantified (Tab. III): trans-9 trans-12, cis-9 trans-13, cis-9 trans-12 and trans-9 cis-12 coeluting with trans-11 cis-15. These isomers were identified by comparing the relative retention times of the chromatographic peaks of the ewe's milk fat samples with the certified vegetable fats and with the milk fat chromatograms analyzed in similar chromatographic conditions in the literature [11, 23, 29].

In contrast to CLA, the other trans$\mathrm{C} 18: 2$ isomers are partly related to negative effects. The trans-9 trans-12 C18:2 isomer is a competitive inhibitor for the conversion of linoleic to arachidonic acid and a completely blocking C20:5 $\omega-3$ formation. It has been suggested that the other trans-C18:2 could affect the essential fatty acid metabolism as well. There are no data in the literature on the trans-C18:2 isomer content in ewe's milk. Although different authors 
Table III. Contents of octadecadienoic acids, linoleic acid (cis-9 cis-12 C18:2) and trans-18:2 isomers (excluding conjugated linoleic acid) in ewe's milk fat (wt \% total methyl esters).

\begin{tabular}{|c|c|c|c|c|c|}
\hline Item & Identification & Mean & Standard deviation & Minimum & Maximum \\
\hline Total C18:2 & & 3.21 & 0.12 & 2.89 & 3.57 \\
\hline \multirow[t]{6}{*}{ Total trans $\mathrm{C} 18: 2$} & & 0.88 & 0.34 & 0.49 & 1.35 \\
\hline & cis-9 cis-12 C18:2 & 2.33 & 0.31 & 1.93 & 2.51 \\
\hline & trans -9 trans -12 & 0.03 & 0.01 & 0.01 & 0.04 \\
\hline & cis -9 trans -13 & 0.31 & 0.11 & 0.19 & 0.47 \\
\hline & cis -9 trans -12 & 0.25 & 0.06 & 0.18 & 0.34 \\
\hline & trans -9 cis $-12+$ trans -11 cis -15 & 0.29 & 0.19 & 0.11 & 0.50 \\
\hline
\end{tabular}

Table IV. Total contents of octadecatrienoic acids, linolenic acid (cis-9 cis-12 cis-15 C18:3) and trans-C18:3 isomers (wt \% total methyl esters).

\begin{tabular}{llcc}
\hline Items & \multicolumn{1}{c}{ Identification } & Mean & Standard deviation \\
\hline Total C18:3 & & 0.80 & 0.21 \\
Total trans-C18:3 & & 0.16 & 0.02 \\
& & 0.63 & 0.25 \\
& cis-9 cis-12 cis-15 18:3 & 0.03 & 0.01 \\
& trans-9 trans-12 trans-15 & & \\
& trans-9 cis-12 trans-15 & 0.09 & 0.02 \\
& + cis-9 trans-12 trans-15 & & \\
& + cis-9 cis-12 trans-15 & & 0.03 \\
& + trans-9 trans-12 cis-15 & 0.04 & \\
& cis-9 trans-12 cis-15 & &
\end{tabular}

$[21,23]$ quantify some of these isomers in cow's milk, it is difficult to establish comparisons with the present work, since in the articles mentioned the cis-9 trans-13 and trans-9 trans-12 coelute in just one peak. Conversely, in our study, the major isomer trans-11 cis-15 could not be resolved from the trans-9 cis-12 isomer. The data show (Tab. III) that the trans-9 trans-12 isomer assessed as negative from a physiological point of view is negligible in ewe's milk fat (0.03\% of total FAME).

The total CLA content in the samples studied is $0.74 \%$ (Tab. I), most of which was RA (over $80 \%$ ). The other corresponds to positional and geometric isomers which are found in low concentrations. The CLA levels measured in this work were slightly lower than those in other studies on ovine cheese [30]. We should, however, bear in mind that the CLA levels may increase during the manufacturing process. The great variability observed between herds $(0.56$ $0.97 \%$ ) could be related to the large range of variation in the trans-11 C18:1 content (Tab. II) which, as mentioned in the previous section, is the RA precursor.

\subsection{Octadecatrienoic isomers}

The linolenic acid content (cis-9 cis-12 cis-15 C18:3) accounts for $79 \%$ of the total C18:3 fraction (Tab. IV). This value $(0.63 \%$ of total FAME) is slightly lower than that given by Wolff [30] for ovine cheese $(0.93 \%$, with a range of variation of 0.60 $1.18 \%$ ), although this author does not indicate whether this percentage includes isomers 
other than linolenic acid. The data on linolenic acid content in cow's milk found in the literature [10], as in the case of linoleic acid, are slightly lower $(0.25-0.60 \%)$.

The trans-C18:3 isomers hardly represent $0.16 \%$ of the total FAME and they correspond to 6 species grouped in 3 peaks and only two isomers quantified individually (trans- 9 trans -12 trans- 15 and cis- 9 trans12 cis-15). As in the case of the trans-C18:2 isomers, there are no data in the literature on ewe's milk for these acids to establish comparisons.

The data of this study, generated from the milk of five ewe herds of different regions, did not show important differences in the content of fatty acids. Concerning the total TFA content, the levels found (4.9\% of total FAME, including CLA) did not differ substantially from those reported in previous studies for other ruminant milk fat. This research also quantified octadecadienoic and octadecatrienoic trans acids, isomers not previously reported in ewe's milk. It is important to know the total TFA content, but it is even more important to know the trans isomer composition of TFA composition. Elaidic and other TFA labeled as unhealthy were found in low concentrations. On the other hand, these results confirm that ewe's milk fat exhibits the highest CLA content and TVA in ruminant milk.

Acknowledgements: This work was supported by the Ministerio de Cienciay Tecnología(Research Project AGL2002-0088-00887) and the Comunidad Autónoma de Madrid (Research Project 07G/0039/2003).

\section{REFERENCES}

[1] Alonso L., Fontecha J., Lozada L., Fraga M.J., Juárez M., Fatty acid composition of caprine milk: major, branched-chain and trans fatty acids, J. Dairy Sci. 82 (1999) 878884.

[2] Aro A., Kosmeijer-Schuil T., van de Bovemkamp P., Hulshof P., Zock P., Katan M.B., Analysis of $\mathrm{C}_{18: 1}$ cis and trans fatty acid isomers by the combination of gas-liquid chromatography of 4,4 dimethyloxazoline derivatives and methyl esters, J. Amer. Oil Chem. Soc. 75 (1998) 977-985.

[3] Christie W.W., Robertson G.W., McRoberts W.C., Hamilton J.T.G., Mass spectrometry of the 4,4-dimethyloxazoline derivatives of isomeric octadecenoates (monoenes), Eur. J. Lipid Sci. Technol. 102 (2000) 23-29.

[4] Destaillats F., Wolff R.L., Precht D., Molkentin J., Study of individual trans- and cis-16:1 isomers in bovine, caprine, and ovine cheese fats by gas-liquid chromatography with emphasis on the trans-3 isomer, Lipids 35 (2000) 1027-1032.

[5] Fay L., Richli U., Location of double bonds in polyunsaturated fatty acids by gas chromatography-mass spectrometry after 4,4-dimethyloxazoline derivatization, J. Chromatogr. 541 (1991) 89-98.

[6] Hayakawa K., Linko Y.Y., Linko P., The role of trans fatty acids in human nutrition, Eur. J. Lipid Sci. Technol. 102 (2000) 419-425.

[7] ISO, Milk and milk products. Extraction methods for lipids and liposoluble compounds. Int. Stand. ISO 14156, IDF 172 Int. Dairy Fed. Brussels, Belgium, 2001.

[8] ISO, Milk fat. Preparation of fatty acid methyl esters. Int. Stand. ISO 15884, IDF 182 Int. Dairy Fed. Brussels, Belgium, 2002.

[9] Iverson J.L., Sheppard A.J., Detection of bovine milk in caprine and sheep cheeses utilizing gas-liquid chromatographic fatty acid data, J. Dairy Sci. 72 (1989) 1707-1712.

[10] Jensen R.G., The composition of bovine milk lipids: January 1995 to December 2000, J. Dairy Sci. 85 (2002) 295-350.

[11] Kramer J.K.G., Blackadar C.B., Zhou J., Evaluation of two GC columns (60-m SUPELCOWAX 10 and 100-m CP Sil 88) for analysis of milkfat with emphasis on CLA, 18:1, 18:2 and 18:3 isomers, and shortand long-chain FA, Lipids 37 (2002) 823-835.

[12] Marai W., Breckenridge W.C., Kuksis A., Specific distribution of fatty acids in the milk fat triglycerides of goat and sheep, Lipids 4 (1969) 562-570.

[13] Le Doux M., Rouzeau A., Bas P., Sauvant D., Occurrence of trans-C18:1 fatty acid isomers in caprine milk: effect of two dietary regimens, J. Dairy Sci. 85 (2002) 190-197.

[14] Mossoba M.M., McDonald R.E., Roach J.A.G., Fingerhut D.D., Yurawecz M.P., Sehat N., Spectral confirmation of trans monounsaturated $\mathrm{C} 18$ fatty acid positional isomers, J. Amer. Oil Chem. Soc. 74 (1998) 125-130.

[15] Mozzon M., Frega N.G., Fronte B., Tocchini M., Effect of dietary fish oil supplements on levels of n-3 polyunsaturated fatty acids, trans acids and conjugated linoleic acid in 
ovine milk, Food Technol. Biotechnol. 40 (2002) 213-219.

[16] Parodi P.W., Distribution of isomeric octadecenoic fatty acids in milk fat, J. Dairy Sci. 59 (1976) 1870-1873.

[17] Parodi P.W., Milk fat component: possible chemopreventive agents for cancer and other diseases, Aust. J. Dairy Technol. 51 (1996) 24-32.

[18] Parodi P.W., Anti-cancer agents in milk fat, Aust. J. Dairy Technol. 58 (2003) 114-118.

[19] Perea S., De Labastida E.F., Najera A.I., Chavarri F., Virto M., De Renobales M., Barrón L.J.R., Seasonal changes in the fat composition of lacha sheep's milk used for Idiazabal cheese manufacture, Eur. Food Res. Technol. 210 (2000) 318-323.

[20] Precht D., Molkentin J., Rapid analysis of the isomers of trans-octadecanoic in milk fat, Int. Dairy J. 6 (1996) 791-809.

[21] Precht D., Molkentin J., Trans-geometrical and positional isomers of linoleic acid including conjugated linoleic acid (CLA) in German milk and vegetable fats, Fett-Lipid 99 (1997) 319-326.

[22] Precht D., Molkentin J., Frequency distributions of conjugated linoleic acid and trans fatty acid contents in European bovine milk fats, Milchwissenschaft 55 (2000) 687-691.

[23] Precht D., Molkentin J., Vahlendieck M., Influence of the heating temperature on the fat composition of milk fat with emphasis on cis-/trans-isomerization, Nahrung 43 (1999) 25-33.

[24] Precht D., Molkentin J., Destaillats F., Wolff R.L., Comparative studies on individual iso- meric 18:1 acids in bovine, caprine, and ovine milk fats by low-temperature highresolution capillary gas-liquid chromatography, Lipids 36 (2001) 827-832.

[25] Ramos M., Juárez M., Chromatographic, electrophoretic and immunological methods for detecting mixtures of milks from different species, Bull. Int. Dairy Fed. 202 (1986) 175187.

[26] Sevi A., Rotunno T., Di Caterina R., Muscio A., Fatty acid composition of ovine milk as affected by solar radiation and high ambient temperature, J. Dairy Res. 69 (2002)181-194.

[27] Soustre Y., Laurent B., Schrezenmeir J., Pfeuffer M., Miller G., Parodi P., Trans Fatty Acids, Bull. Int. Dairy Fed. 377 (2002) 20-31.

[28] Turpeinen A.M., Mutanen M., Aro A., Salminen I., Basu S., Palmquist D.L., Griinari J.M., Bioconversion of vaccenic acid to conjugated linoleic acid in humans, Amer. J. Clinical Nutr. 76 (2002) 504-510.

[29] Ulberth F., Henninger M., Quantitation of trans fatty acids in milk fat using spectroscopic and chromatographic methods, J. Dairy Res. 61 (1994) 517-527.

[30] Wolff R.L., Content and distribution of trans18:1 acids in ruminant milk and meat fats. Their importance in European diets and their effect on human milk, J. Amer. Oil Chem. Soc. 72 (1995) 259-272.

[31] Zhang J.Y., Yu Q.T., Liu B.N., Huang Z.H., Chemical modification in mass spectrometry IV 2-Alkenyl-4,4-dimethyloxazolines as derivatives for the double bond location of longchain olefinic acids, Biomed. Environ. Mass Spectrom. 15 (1988) 33-44.

To access this journal online: www.edpsciences.org 